sometimes misleading analogies may be overlooked, for his speculations, backed by the experimental facts that he has marshalled, will admirably serve the purpose of challenging immunologists to explain those aspects of antibody formation that are inadequately covered by current hypotheses.

\section{A. A. Miles.}

\section{LOGICAL FOUNDATIONS OF PSYCHO-ANALYSIS}

Psychoanalytical Method and the Doctrine of Freud By Dr. Roland Dalbiez. Vol. 1 : Exposition. Translated from the French by T. F. Lindsay. Pp. xvi+ 415. Vol. 2: Discussion. Translated from the French by T. F. Lindsay. Pp. xii +331 . (London, New York and Toronto : Longmans, Green and Co., Ltd., 1941.) 40s. net.

$\mathrm{T}^{\mathrm{T}}$ is fitting that a critical survey of Freud's writings should appear at this time. Insistent questions are provoked by the War. We witness the spectacle of a civilized people reduced to barbarism within a few years and wonder how this is possible. Are wars, it is often asked, simply the outcome of unconscious aggressive impulses? How deep is the impress that civilized living makes upon the psyche? Are humane dispositions wholly part of ontogenesis, and can no such dispositions be transmitted genetically ? To what extent can re-education in the postwar world nullify the effects of totalitarian propaganda instilled during the impressionable years of youth, and what are the limits of variation in conduct that the same individuals may express under diverse conditions? No satisfactory answer to these and other urgent questions can be attempted without enlisting the aid of psycho-analysis. Indeed, it is probably true to say that without psycho-analysis, contemporary social behaviour is unintelligible and no coherent picture of human failings and aspirations in the modern world can be drawn without invoking its theories, provisional though they may be.

The foundations of psycho-analysis still lie in the writings of Freud. The reader of Dr. Dalbiez's work should therefore be led to the conclusion that the task of disentangling Freud's analytic technique from the theory with which it is interwoven and of subjecting both technique and theory to close examination were well worth undertaking, and that Dr. Dalbiez has acquitted himself with rare competence. He brings to psycho-analysis a standard of logical demonstration that has long been painfully lacking in this field. Several chapters, particularly the one entitled "The Various Neuroses", are noteworthy for their qualities of lucid exposition.

A specially useful contribution is the systematic attempt to relate the work of Freud to that of Pavlov. This effort to unify two independent hypotheses formulated in very different terms meets with a large measure of success. Even the much-disputed Eidipus conflict is readily translated into the language of reflexology, and is shown to result from a clash between the processes of excitation and inhibition, the genital reflex mechanisms failing to differentiate between two similar stimuli. Dr. Dalbiez maintains that the development of the sexual impulse reveals itself in a progressive differentiation of object. This view is presented as more in accordance with the facts than is the Freudian notion of sexual development as a succession of perverse phases culminating in normal heterosexuality. The belief that sexual development proceeds by integration of separate responses is in line with recent experiments on aggressive impulses in certain animal species.

Mention should be made of the discussion on symbolism, which clears up many confusions in the literature. In particular, the retrospective, reductive, causal interpretation of symbolism which is adopted by Freud is contrasted with the prospective, synthetic, teleological view of Silberer.

A number of criticisms rise to mind. The size of the second volume could have been much reduced; its matter is scarcely commensurate with its bulk. One may blame the philosophic training of the author for a number of purely academic discussions. The chapter dealing with the psychoses in the first volume can scarcely be regarded as having achieved its aim. About a third of this chapter is devoted to a criticism of Dr. de Clérambault's theories of mental automatism, an allocation of space which is surely unmerited. It is disappointing to find that aggressive behaviour is not accorded due recognition. The word 'aggression' does not even appear in the index. The world of Dr. Dalbiez seems to be the peaceful world of the philosopher, and one would gather that Freud attached little or no importance to aggressive impulses-a deduction which would be very misleading. JoHN COHEN.

\section{MATERIALS AND STRUCTURES}

\section{Materials and Structures}

By D. A. R. Clark. Pp. xii +384. (London, Glasgow and Bombay : Blackie and Son, Ltd., 1941.) 25s. net.

\section{Practical Design of Simple Steel Structures}

By Dr. David S. Stewart. Vol. 1: Shop Practice, Riveted Connections and Beams, etc.; a Text-Book suitable for Civil Engineers, Structural Engineers, Road and Railway Engineers, and Students at Universities and Technical Colleges. Second revised and enlarged edition. Pp. xv +184 . (London : Constable and Co., Ltd., 1941.) 14s. net.

THE first of these two books has been written to meet the needs of students preparing for exam. inations in strength of materials and structures such as those in Part I of the University of London degree, Higher National Certificate and engineering institutions' syllabuses. These demand knowledge of the calculus, and the book assumes a similar standard. It is therefore disconcerting to find several pages given up to the working out in detail of the formulæ for the moments of inertia of such simple sections as form the most elementary exercises in integration. If the reader requires to be shown the detailed operations in the case of these geometrical sections, by how much the more must he need some light on the methods by which practical sections can be evaluated. From this point of view the author has not gone far enough to satisfy the needs of students at the stage indicated.

The pattern of the book is determined by its devotion to the subject of structures, and this gives it a distinct character. Instead of ranging over the aspects of strength of materials which appertain to machines, it confines itself to those concerned with structures and its examples are drawn from this branch of engineering. It is therefore to the structural engineering student in particular that it will appeal and whom it will most greatly help. He will find it a valuable medium of preparation for his profession 